\title{
CUSTOMER SATISFACTION OF SELECTED BRANCHES OF BANK OF CEYLON IN BATTICALOA DISTRICT
}

\author{
Ismail.M.B.M \\ Department of Management, Faculty of Management and Commerce \\ South Eastern University of Sri Lanka, Oluvil \\ mbmismail1974@gmail.com
}

\begin{abstract}
Studies have also found that different studies have found different factors for customer satisfaction. But, these studies were carried out in different organsational settings such as service industries. This study is conducted in two selected bank branches of Bank of Ceylon in Batticaloa District. This study attempts to know about factors and factor rankings for customer satisfaction. Sample size considered in this study is 100 customers. These customers were contacted during the banking hours while they finish their banking activities without disturbing them and banking business. Results of the reliability revealed that items are higher reliable (0.700). Since value of Kaiser-Meyer-Olkin is 0.519 which reveals a satisfactory value. Bartlett's Test of Sphericity which is measured by approximate chi square. Value of significant approximate chi-square is 1637.840 with 231 degrees of freedom. Initial and extracted communalities for factors are 1 and greater than 0.6. Total eigenvalues that are greater than 1 is selected. There are 8 factor components that explain around $81 \%$ of variation towards customer satisfaction. It is concluded that, on the basis of the factor score, factors can be ranked.
\end{abstract}

Keywords: Customer, Satisfaction.

\section{INTRODUCTION}

Customer satisfaction is one of the most studies areas in marketing. From the historical perspective, a great deal of the works in the customer satisfaction area began in the 1970's when consumerism was on the rise. Customer satisfaction is doing what the customer expects. In a sense being adequate service people do not talk about adequate service. People tell anyone who will listen about really bad service or really satisfactory service. Thomas \& Sesser (1995) explained customer satisfaction is the individual's perception of the performance of the product or service in relation to customer expectations. As noted the concept of customer satisfaction is a function of customer expectations. A customer whose experience matches expectations will be dissatisfied. Whose experience match expectation will be satisfied and customer whose expectations are exceeds will be very 
satisfied or delighted. Studies found that measuring customer satisfaction brings increased sales and profits. Studies found that unhappy customers may create great loss to a firm. Studies have also found that different studies have found different factors for customer satisfaction. Mayson \& Hynes (1973); Vivash (1972); Michal 1972) found different factors for customer satisfaction. These studies used descriptive and correlation analyses for their analytical technique. In addition to these, these studies were carried out in different organsational settings such as service industries. Albeit, this study is conducted in two selected bank branches of Bank of Ceylon in Batticaloa District.

\subsection{Research Question And Objective}

This study asks "is it possible to rank the factors of customer satisfaction" as research question. This research question is translated into research objective. Thus, this study attempts to know about factors and factor rankings for customer satisfaction.

\subsection{Significance of the Study}

This study is important for various reasons. Studies found that customer satisfaction is important for organizational survival. The service firm has no reason to exist to exist. Studies found that customer satisfaction deals with pro-activity. Every service business needs proactively define and measure customer satisfaction. Studies found that customer satisfaction is used to gauge firm's progress. It has been stated that firm's progress depends on customer satisfaction. Studies found that customer satisfaction determines customer behavior. Wandon (1971) forwarded customer satisfaction had been the chief common deciding factor for the customer's willingness to buy product. Studies have found that customer satisfaction plays significant role in marketing. Evan \& Berman (2003) said that customer satisfaction is a crucial element is successful marketing. Customer satisfaction is the degree to which there is a match between a customer's expectations of a good or services and actual performance of that good or service including customer service. Studies found that customer satisfaction leads to customer orientation and profits. Antaneo \& Teotaneo (2002) found that customer satisfaction leads to customer orientation and profits to organization.

\section{REVIEW OF LITERATURE}

Kotler (2003) defined satisfaction as a person's feelings of pleasure or disappointment resulting from comparing a product's perceived performance (or outcome) in relation to customer expectations. If the performance falls short of expectations, the customer is dissatisfied. If the performance matches the expectations, the customer is satisfied. If the performance exceeds expectations, the customer is highly satisfied or delighted. Keith (1991) compared actual outcomes to those that are culturally acceptable. It is compared gains that are in equal and the loser is dissatisfied. 
There are number of studies with respect to customer satisfaction.

Ismail \& Velnamy (2013) studied about performance and patient satisfaction in public health service organizations in Eastern Province of Sri Lanka. Study found that there is a high strength of patient satisfaction. Ismail \& Velnampy (2013) association between performance of PHSO and patient satisfaction. Ismail \& Velnampy (2013) found that core services, human element of the service and non- human of the service factors in the model explain $94 \%$ of total variation for found that core services, human element of the service and nonhuman of the service factors in the model explain $94 \%$ of total variation for patient satisfaction.

Evans \& Berman (2003) found several determinants of customer satisfaction. They are friendly employees, helpful employees, courteous employees, knowledgeable employees, quick services, billing clarity, good value, service quality, competitive pricing, billing timelines and accuracy of billing. Stewart \& Jacklyn (1995) studied about tracking consumer satisfaction in the United States on the basis of an analysis of ASCI results. It was found that business often make three common mistakes that lead to lower levels of customer satisfaction. They are (1) customer service as a cost rather than as an investment; (2) maintenance of customer satisfaction; (3) linkage of customer satisfaction to bottom line employees. Journal of Business Studies
Dinuku \& Ranjani (2003) analyzed the customer satisfaction in Srilankan retail banking. The findings indicate that service quality is more important in determining satisfaction than service features or price of the different service quality dimensions. Leve \& Dougall (1996) attempted to identify the determinants of customer satisfaction in retail banking using a sample of 325 respondents in Canada. It was found that service quality, service features, customer complaint handling and situational factors are the possible determinants of the satisfaction.

Antaneo \& Teotaneo (2002) studied about customization in marketing for electronic commerce and it's contribution from Holland. Information technology, the ability for the use of net work, commercial knowledge, the result of work in marketing and the marketing P's contribute to each market. Research findings in banks have indicated that customer satisfaction and customer's evaluation of service quality can be influenced by their perception towards a combination of factors such as product/ service, customer service, pricing/ rates, location/ convenience to access and communication, etc.

\subsection{Factors of Customer Satisfaction}

The review of literature identified the following factors for customer satisfaction. They are (1) friendly employees, (2) helpful employees, (3) courteous employees, (4) knowledgeable employees, (5) quick 
services, (6) billing clarity, (7) billing timelines, (8) accuracy of billing, (9) good value, (10) competitive pricing, (11) customer service, (12) maintenance of customer satisfaction, (13) service quality, (14) service features, (15) price/ rate, (16) customer complaint-handling, (17) situational factors, (18) the ability for the use of information network, (19) commercial knowledge, (20) product/ service, (21) location/ convenience to access, (22) communication.

\section{METHODOLOGY}

\subsection{Sample Size}

Sample size considered in this study is 100 customers. These customers were contacted during the banking hours while they finish their banking activities without disturbing them and banking business.

\subsection{Methods Of Data Collection}

For this study, primary source of data are used to collect data. Questionnaires are used as an instrument for collecting the data. Questionnaire had been designed into personal profile and factors for customer satisfaction. Data were collected during the $4^{\text {th }}$ quarter of 2015.

\subsection{Techniques Of Data Analysis}

This research used few statistical techniques such as reliability technique and factor analysis for getting results of the data collected.

\section{RESULTS AND DISCUSSION OF FINDINGS}

\subsection{Reliability}

Reliability for friendly employees, helpful employees, courteous employees, knowledgeable employees, quick services, billing clarity, billing time lines, accuracy of billing, good value, competitive pricing, customer service, maintenance of customer satisfaction, service quality, service features, price or rate, customer complaint handling, situational factors, the ability for the use of information network, commercial knowledge, product or service, location or convenience to access and communication is statistically calculated using Cronbach's Alpha. The value of Cronbach's Alpha is 0.700 . Table 4.1 tabulates the reliability statistics.

Kaiser-Meyer-Olkin is a measure of sampling adequacy. Studies found that this value should be greater than 0.5 . Value of

Table 4.1: Reliability Statistics

\begin{tabular}{cc}
\hline Cronbach's Alpha & N of Items \\
0.700 & 22 \\
\hline
\end{tabular}

Kaiser-Meyer-Olkin is 0.519 which reveals a satisfactory value. This means that sample taken in this study is sufficient for making factor analysis. Bartlett's Test of Sphericity is another test that is conducted before running factor analysis. Bartlett's Test of Sphericity is a statistical analysis that is measured by approximate chi square. Value of significant approximate chi- square is 1637.840 with 231 degrees of freedom. 
Values of Kaiser-Meyer-Olkin and Bartlett's

Test of Sphericity are revealed in Table 4.2.

Table 4.2: KMO and Bartlett's Test

\begin{tabular}{|c|c|c|}
\hline \multicolumn{2}{|c|}{$\begin{array}{l}\text { Kaiser-Meyer-Olkin Measure of } \\
\text { Sampling Adequacy. }\end{array}$} & .519 \\
\hline \multirow[t]{3}{*}{$\begin{array}{l}\text { Bartlett's Test } \\
\text { of Sphericity }\end{array}$} & $\begin{array}{l}\text { Approx. Chi- } \\
\text { Square }\end{array}$ & 1637.840 \\
\hline & Df & 231 \\
\hline & Sig. & .000 \\
\hline
\end{tabular}

\subsection{Communalities}

Initial and extracted communalities for factors are 1 and greater than 0.6. These vales for extracted communalities are satisfactory. Communalities are tabulated in Table 4.3.

\begin{tabular}{lcc}
\hline \multicolumn{3}{c}{ Table 4.3: Communalities } \\
\hline & Initial & Extraction \\
Friendly employees & 1.000 & .856 \\
Helpful employees & 1.000 & .801 \\
Courteous employees & 1.000 & .807 \\
Knowledgeable & 1.000 & .862 \\
employees & & \\
\hline Quick services & 1.000 & .685 \\
Billing clarity & 1.000 & .780 \\
Billing timelines & 1.000 & .929 \\
Accuracy of billing & 1.000 & .857 \\
& & \\
Good value & 1.000 & .839 \\
Competitive pricing & 1.000 & .804 \\
Customer service & 1.000 & .810 \\
Maintenance & 1.000 & .733 \\
customer satisfaction & & \\
Service quality & 1.000 & .819 \\
Service features & 1.000 & .639 \\
Price or rate & 1.000 & .837 \\
& &
\end{tabular}

$\begin{array}{lcc}\begin{array}{l}\text { Customer complaint } \\ \text { handling }\end{array} & 1.000 & .934 \\ \begin{array}{l}\text { Situational factors } \\ \text { The ability for the use } \\ \text { of information }\end{array} & 1.000 & .690 \\ \text { network } & .731 \\ \begin{array}{l}\text { Commercial } \\ \text { knowledge }\end{array} & 1.000 & .755 \\ \begin{array}{l}\text { Product or service } \\ \text { Location } \\ \text { convenience to access } \\ \text { Communication }\end{array} & 1.000 & .942 \\ \text { Extraction Method: Principal Component } \\ \text { Analysis. }\end{array}$

\subsection{Total Variance}

Total Variance is explained by eigenvalues and total variance before and after rotation. Total eigenvalues that are greater than 1 is selected. There are 8 factor components that have been created out of 22 factors. These factors explain around $81 \%$ of variation towards customer satisfaction. Eigenvalues, total variance before and after rotation are tabulated in table 4.4 .

\subsection{Scree plot}

Scree plot is a graphical representation of total variance. $81 \%$ of the total variance is graphically presented using factor components and eigenvalues. Figure 4.1 depicts the scree plot.

\subsection{Factor score}

Factor score is calculated on the basis of factor loadings and factor score coefficient. On the basis of the factor score, factors are ranked. Factor score and factor ranking are tabulated in Table 4.5. 


\section{CONCLUSION}

Results of the reliability revealed that items are higher reliable (0.700). Since value of Kaiser-Meyer-Olkin is 0.519 which reveals a satisfactory value. Bartlett's Test of Sphericity which is measured by

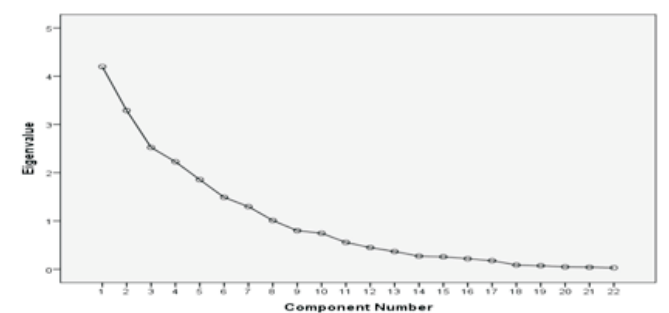

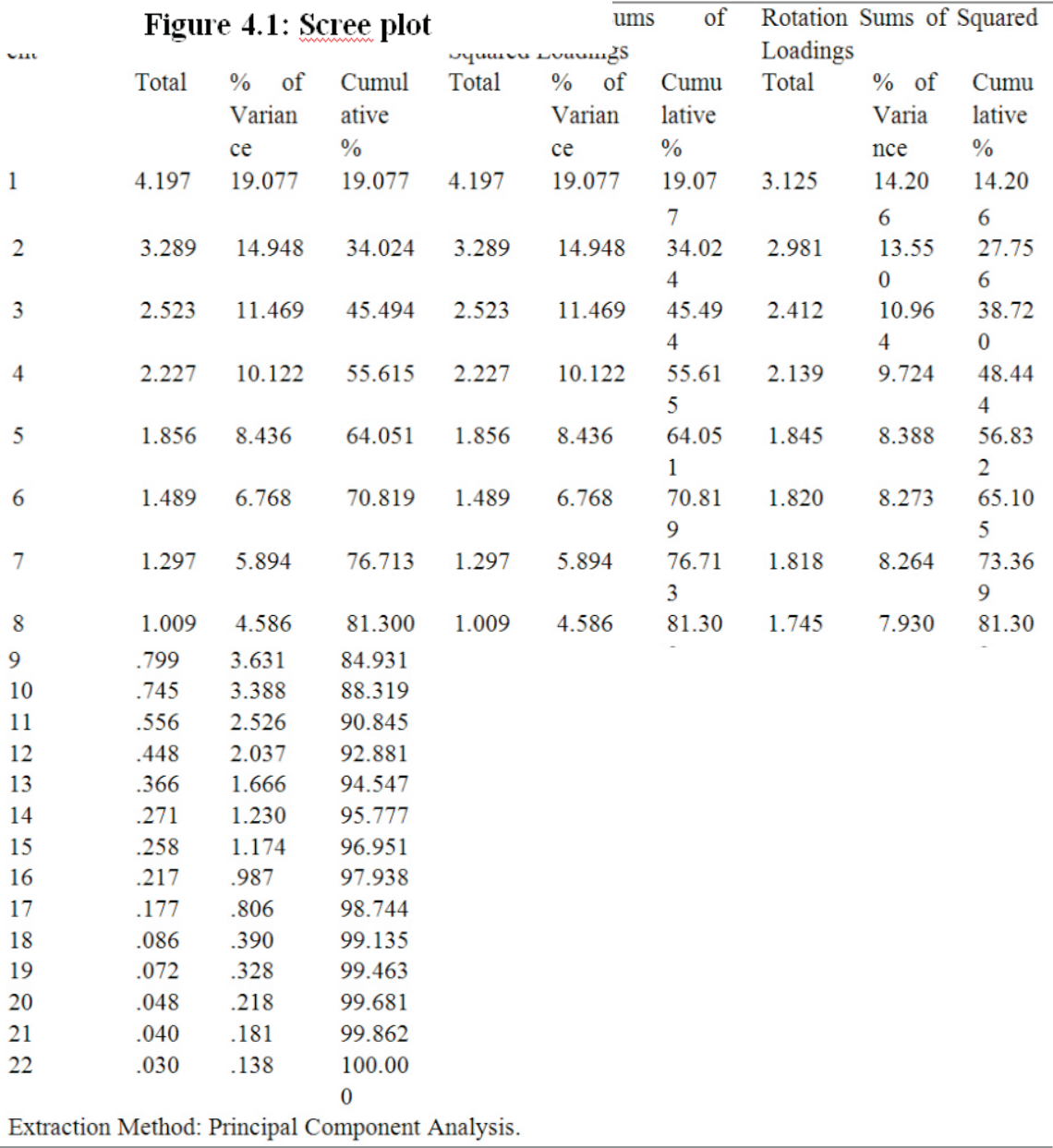

Extraction Method: Principal Component Analysis.

\section{Explained}

ums of Rotation Sums of Squared Loadings approximate chi square. Value of significant approximate chi- square is 1637.840 with 231 degrees of freedom. Initial and extracted communalities for factors are 1 and greater than 0.6. Total eigenvalues that are greater than 1 is selected. There are 8 factor components that explain around $81 \%$ of variation towards customer satisfaction. On 
Table 4.5: Factor score and factor rank

\begin{tabular}{|c|c|c|c|c|c|}
\hline & $\begin{array}{l}\text { Factor } \\
\text { loadings }\end{array}$ & $\begin{array}{l}\text { Factor } \\
\text { score } \\
\text { coefficient }\end{array}$ & $\begin{array}{l}\text { Individual } \\
\text { factor } \\
\text { score }\end{array}$ & $\begin{array}{l}\text { Factor } \\
\text { score }\end{array}$ & Rank \\
\hline Billing timelines & 0.925 & 0.321 & 0.296925 & & \\
\hline Customer complaint handling & 0.937 & 0.328 & 0.307336 & & \\
\hline Product or service & 0.952 & 0.352 & 0.335104 & 0.939365 & 3 \\
\hline Courteous employees & 0.602 & 0.175 & 0.10535 & & \\
\hline Good value & 0.877 & 0.31 & 0.27187 & & \\
\hline $\begin{array}{l}\text { The ability for the use of } \\
\text { information network }\end{array}$ & 0.835 & 0.294 & 0.24549 & & \\
\hline Communication & 0.927 & 0.331 & 0.306837 & 0.929547 & 5 \\
\hline Billing clarity & 0.865 & 0.396 & 0.34254 & & \\
\hline Price or rate & 0.887 & 0.384 & 0.340608 & & \\
\hline Commercial knowledge & 0.826 & 0.357 & 0.294882 & 0.97803 & 1 \\
\hline Accuracy of billing & 0.876 & 0.446 & 0.390696 & & \\
\hline Situational factors & 0.649 & 0.347 & 0.225203 & & \\
\hline Location or convenience to access & 0.866 & 0.412 & 0.356792 & 0.972691 & 2 \\
\hline Knowledge of employees & 0.914 & 0.533 & 0.487162 & & \\
\hline Service quality & 0.889 & 0.508 & 0.451612 & 0.938774 & 4 \\
\hline Helpful employees & 0.852 & 0.501 & 0.426852 & & \\
\hline Customer service & 0.854 & 0.513 & 0.438102 & 0.864954 & 7 \\
\hline Quick service & 0.784 & 0.461 & 0.361424 & & \\
\hline $\begin{array}{l}\text { Maintenance of customer } \\
\text { satisfaction }\end{array}$ & -0.601 & -0.310 & 0.18631 & & \\
\hline Service features & 0.766 & 0.439 & 0.336274 & 0.884008 & 6 \\
\hline Friendly employees & 0.873 & 0.594 & 0.518562 & & \\
\hline Competitive pricing & 0.706 & 0.413 & 0.291578 & 0.81014 & 8 \\
\hline
\end{tabular}

the basis of the factor score, factors are location or convenience to access represent ranked. Billing clarity, price or rate and the factor score of 0.972691 as ranked into 2 . commercial knowledge composes the factor Billing time lines, customer complaint score of 0.97803 that is ranked into 1 . handling and product or service have the Accuracy of billing, situational factors and factor score of 0.939365 as ranked into 3 . Journal of Business Studies 24 Issue II - 2016 
Knowledge of employees and service quality that has a factor score of 0.938774 which has been ranked into 4 . Courteous employees, good value, the ability for the use of information network and communication have the factor score of 0.929547 which is ranked into 5. Quick service, maintenance of customer satisfaction and service features have the factor score of 0.884008 as placed in $6^{\text {th }}$ rank. Helpful employees and customer service have a factor score of 0.864954 that is scored into 7 . Friendly employees and competitive pricing have the factor score of 0.81014 that is ranked as $8^{\text {th }}$ place.

\section{REFERENCES}

Antaneo, A. \& Teotaneo, B. (2002). Management. International Journal of Management, 1(1) 1-10.

Evan, J. R. \& Berman, B. (2003). Retail management: a strategic approach. Upper Saddle River: Prentice Hall.

Ismail, M. B. M. \& Velnampy, T. (2013). Performance and Patient satisfaction in Public Health Service Organizations (PHSO) in Eastern Province of Sri Lanka. European Journal of Applied Social Sciences Research (EJASSR) 1(3).

Ismail M. B. M. \& Velnampy, T. (2013). Determinants of Patient Satisfaction (PS) in Public Health Service Organizations (PHSO) in Eastern
Province of Sri Lanka. The USV Annals of Economics and Public Administration, 13(2) 18.

Keith, B. \& Amato, P. R (1991). Parental divorce and the well-being of children: a meta-analysis. Psychology Bulletin, 110(1) 26-46.

Kotler, P. (2003). Marketing Management, $11^{\text {th }}$ Edition, India: Prentice Hall.

Levesque, T.J. \& McDougall, G. H. G. (1996). Determinants of customer satisfaction in retail banking. International Journal of Bank Marketing, 14(7) 12-20.

Mayson, A. \& Hynes, B. (1973). Characteristics of Consumer Complainants: Implications for Marketing and Public Policy. Journal of Public Policy \& Marketing, 3, 6784.

Michal, B. (1972). Business Continuity Management: Building an Effective Incident Management Plan. International Journal of Management, 1, 11-21

Stewart, A. \& Jacklyn, B. (1995). Optimizing Human Capital with a Strategic Project Office. International Journal of Management, 1, 1-10. 
Thomas, O. J. \& Sesser, W. E. (1995). Why Satisfied Customers Defect. Market Research, 1(1) 1-10

Vivash, A. (1972). Strategic Water Management: International Experience and Practices. International Journal of Management, 1(1), 1-10.
Wandon, A. (1971). Management. International Journal of Management, 1(1) 1-10

Wijetunga, D. \& Goonatillake, R. (2003).

Retail Banking. Srilankan Journal of Management, 8(3\&4). 